\title{
Hand Digit 5
}

National Cancer Institute

\section{Source}

National Cancer Institute. Hand Digit 5. NCI Thesaurus. Code C52838.

The fifth and smallest finger from the radial side of the hand. 